\title{
Immune Hemolytic Anemia
}

National Cancer Institute

\section{Source}

National Cancer Institute. Immune Hemolytic Anemia. NCI Thesaurus. Code C91782.

An acquired anemia resulting from immune-mediated destruction of the red blood cells.

Causes include autoimmune disorders, blood transfusions, and drugs. 